Megacephalon mileo. The reviewer corrects, by the way, my calling the Celebean whimbrel Numenius pheopus, saying that it is probably $\boldsymbol{N}$. uroprgialis, but these two names are synonymical, cf. for instance, Salvadori, Orn. Pap., iii., 332, 1832, sub $N$. variegatus. As to its nesting on small trees "small brushes" were intended to be implied (see Legge, "Birds of Ceylon," I880, p. 913).

Royal Zoological Museum, Dresden, March 22

\section{Crystals of Lime.}

IT was pointed out to me by Mr. W. J. Pope, of the City and Guilds of London Institute, that a lime cylinder which had been used in the lantern during a lecture had become distinctly crystalline where affected by the oxyhydrogen flame.

Examined under the microscope by polarized light, the crystals are seen to be well-defined cubes with striated faces. When immersed in water they break up and give rise to minute doubly refracting plates of rhombic outline, behaving in this respect like ordinary lime; the cubic crystals, however, are less rapidly affected by exposure either to air or water than is amorphous lime.

Lime is commonly stated to be infusible at the temperature of the oxyhydrogen blow-pipe; and the only crystals previously recorded, so far as I know, are those obtained by Brigelmann, by fusing calcium nitrate (Annalen der Physik und Chemie, ii. p. 466 , iv. p. $277,1877-78$ ). It seems, therefore, worthy of notice that they are possibly always formed upon the surface of the lime cylinders by the action of the oxybydroyen flame.

The crystals resemble in all respects those described by Brigelmann. The jet used on the present occasion was an ordinary blow-through jet.

H. A. Miers.

Foreign Substances attached to Crabs.

I AM giad to see that Mr. Garstang agrees with me in regarding the presence of the Ascidians on Hyas as accidental.

I had no intention of decrying the value of $\mathrm{Mr}$. Garstang's experiments with Ascidians, but his rule might, perhaps, be limited to those memhers of the group to which it can be proved to apply. Under naturnl conditions it apparentlv fails to apply to $P$. corrugata and $M$. arenosa. As to the latter, Prof. McInto-h assures me that he has frequently found it in the stomach of the cod and haddock.

The appreciation of the $\operatorname{cod}$ for $A$. mesembryanthemum is, I think, sufficiently proved by the fact that the latter is one of the most successful cod-baits used here.

St. Andrews Marine Laboratory, March 29.

Wimshurst Machine and Hertz's Vibrator.

IT may interest those who wish to repeat Hertz's experiments on electro-magnetic radiation to know that many of these can be lone very well by using a small Wimshurst machine in place of the usual induction coil and battery. The vibrator and resonator which we used were like those described in NATURE (vol. xxxix. p. 548), and the Wimshurst machine had two I2-inch plates (giving at most with the jars on a 4 -inch spark). The wires from the vibrator, instead of being connected with an induction coil, were connected with the two outer coatings of the jars of the machine. The machine spark-gap and the vibrator spark-gap should be so adjusted that when a spark occurs at the former one also occurs at the latter. With the apparatus described we got good results when the spark-gaps were $38 \mathrm{~mm}$. and $3 \mathrm{~mm}$. respectively. The outer coatings of the jars are only connected together by the wood of the machine, but it is sometimes an advantage to put a few inches of damp string between the balls of the vibrator.

This combination, is obviously a modification, adapted to work a Hertz vibrator, of one of Dr. Lodge's well-known Leyden jar arrangements.

No doubt many persons have connected the vibrator directly with the terminals of the machine, but this arrangement does not work nearly so well.

T. A. Garretr.

W. LUCAS.

THE INSTITUTION OF NAVAL ARCHITECTS.

$\mathrm{THE}$ annual meeting of the Institution of Naval Architects was held under the presidency of Lord Ravensworth, on Wednesday, Thursday, and Friday of last week. There was a fair list of papers on the programme, although at one time, shortly before the meeting, it was leared that there would be a sad lack of contribu tions from members. At the last minute, however, one or two papers came in, and the list, although perhaps below the average in the importance of the memoirs. was of passable interest.

The following is a consecutive enumeration of the business that was transacted at the meeting:-

Wednesday, March 26th: morning sitting-Annual Report of the Council, an 1 other routine business; Address by the President. Paper read and discussed-Notes on the recent naval manceuvres, by Mr. W. H. White, F.R.S., Director of Naval Construction

Thursday, March 27th: morning sitting-The Maritime Conference, by Rear-Admiral P. H. Colomb; strength of ships, with special reference to distribution of shearing stress over transverse section, by Prof. P. Jenkins; steatite as a pigment for anti-corrosive paints, by Mr. F. C. Goodall. Evening sitting-On the evaporative efficiency of boilers, by Mr. C. E. Stromeyer; on the application of a system of combined steam and hydraulic machinery to the loading, discharging, and steering of steam-ships, by Mr. A. B. Brown; the revolving engine applied on ship-board, by Mr. Arthur Rigg.

Friday, March 28th : morning sitting-On leak stopping in steel ships, by Captain C. C. Penrose Fitzgerald, R.N.' on the variation of stresses on vessels at sea due to wave motion, by Mr. T. C. Read; spontaneous combustion in c.sal ships, by Prof. Vivian Lewes. Evening sitting-Experiments with life-boat models, by Mr. J. Corbett ; on the screw propeller, by Mr. James Howden.

The annual dinner was held on the evening of Wednesday.

Out of the above list of a dozen papers there were fewer than usual of scientific interest, ant, indeed, in one or two instances they were not either distinguished by practical interest. Mr. White's paper, which formed the pièce de resistance of the meeting, was of military rather than scientific importance, and was chiefly notable from the number of admirals that took part in the discussion; indeed, the whole naval contingent of the Board of Admiralty was present to hear the paper read. Admiral Colomb's paper on the recent Washington Maritime Conference was practically reduced to a consideration of the rule of the road at sea. The general opinion of the authorities assembled appeared to be that the present rulc of the road is very well as it stands, with the exception that the "holding-on ship" should not be required, or even allowed, to slacken her speed. This seems in conformity with common-sense. If two ships are converging towards a point, say at right angles to each other, and one shifts her helm to go under the other's stern, if the second, or holding-on ship, slacken speed, the probability will be that the giving-way ship will crash into the other's broadside or cross her bows; in the latter case, there is probability that the holding-on ship will give the other her stem. What is most wanted when danger of collision arises, is certainty on each vessel as to what the olher may be going to do. If the holding-on ship never slacken speed-is not allowed to slacken speed-then the other vessel knows exactly what course to take; as the law stands, the quartermaster, or officer in charge, is never quite sure until the last minute, e-pecially at night, whether the other ship considers there is danger of collision or not, and, therefore, whether she will slacken or keep to full speed. We anticipate the proposed alteration, if put in force, will greatly lessen the list of collisions.

The memoir contributed by Prof. Jenkins on the strength of ships was decidedly the most important contribution to naval science of this year's meeting. The paper will open up to the majority of those practi- 